\title{
A Pianística Multifacetada de Francisco Mignone*
}

\author{
José Eduardo Martins
}

Francisco Mignone poderia ter sido apenas pianista. Destinação clara mostrava-se delineada e o piano, instrumento a que sempre estivera ligado, apresentavase como decorrência de talento nato. Reflexão metafísica voltada à perpetuação, à imortalidade, fê-lo cedo ampliar os caminhos. É quando sente e compreende a atração pela composição:

Há algo de interessante no concertista; quando ele desaparece, automaticamente desaparece o trabalho que ele fez nesse efêmero período de tempo. O concertista muito raramente é lembrado, ao passo que o compositor é diferente na medida em que ele deixa uma obra. É um patrimônio eterno que ele deixa para sua Pátria. ${ }^{1}$

Pianismo e composição, paralelamente, percorrem a trajetória de Mignone. A diversidade dos gêneros abordados em organizações instrumentais variadas, assim como para a voz em suas principais destinações musicais, apenas dimensiona a prioridade em escrever para piano. É este o instrumento preferencial, o desaguadouro das múltiplas tensões, homogêneas no seu todo.

Tchaikovsky observaria aos seus alunos que "o piano não é somente um instrumento de virtuosidade, é também um órgão de prospecção, um meio de contato com a realidade musical". 2 Para Mignone, o piano é parte integrante de um universo que tem origem na atividade musical de seu progenitor, flautista. $O$ piano, cultivado em São Paulo desde meados do século XIX, vai se tornando, com o correr das décadas, o instrumento da burguesia, elemento indispensável nos serões familiares e nas audições oficiosas e oficiais. Francisco Mignone, desde a mais tenra infância, toma contato pleno com o piano que, na passagem do século, vivia um período de ascendência sobre uma sociedade que buscava a imperativa elevação num meio acanhado, através dos ingredientes culturais. Flauta e violâo, audicionados no cotidiano, estão entre os instrumentos preferenciais evocados nas criações pianísticas de caráter urbano do compositor.

Bem jovem, o pianista se apresenta executando o primeiro movimento do concerto em Lá menor de Grieg. Convívio com o repertorio pianístico romântico, aptidão natural para o instrumento sob os aspectos físico e perceptivo corroboram o aceitar a importância do piano em seu destino. Mignone compreende cedo que a facilidade técnico-pianística lhe é absolutamente natural e saberá dessa qualidade cristalina extrair, quando do exercício da composição, a transparência da linguagem tecladística mesmo nas mais urdidas passagens.

Francisco Mignone foi um dos compositores que melhor escreveram para piano. A "transcendência" pianística, que para muitos compositores se antepôe - como obstáculo ou necessidade forçada da demonstração virtuosística - à clareza, é para 
Mignone o discurso natural. Poder-se-ia acrescentar que raros são os compositores que escreveram para piano, na transcendência, de maneira tão adequada e "fácil".

O transcendente da obra para piano de Mignone origina-se na conditio sine qua non da improvisação. Mignone, improvisador nato, questionado certa vez por este intérprete, não hesitou em considerar a sua criação "o improviso claborado", pois o fio condutor do criar espontâneo o levava a considerar, quando do verter para o papel, a obra com todos os ingredientes estruturais. Esta espontaneidade, instante único da criação, unida à constituição do pianista que possuía dotes físicos em que a grande abertura das mãos era característica, tornava a escrita musical, quando o desiderato era francamente pianístico, difícil e paradoxalmente fácil. Percebese que o idiomático técnico-pianístico de Mignone é vertido de dentro para fora e que seu código técnico-tecladístico existiu desde a dominação técnica instrumental ocorrida ainda nos anos saídos da juventude.

As particularidades escriturais ficam demonstradas em compartimentos distintos. Se as obras de cunho urbano possuem muito do técnico-pianístico das obras de fundamentação abstrata, é contudo nestas que o transcendente aflora e um verdadeiro laboratório é erigido, no sentido de dar forma a incisos, motivos, desenhos, processos elaborados que têm a marca do transcendente, visando o intérprete. É ele o destinatário da obra. Sente-se claramente em Mignone, mesmo em não desprezando em nada o seu código, a compreensão que tem de cada intérprete dedicatário. E aí reside um dos segredos de Mignone. Nas Sonatas, nos Estudos Transcendentais, nos Prelúdios e nas obras para piano e orquestra, como as Fantasias Brasileiras, e mais significativamente no Concerto, percebe-se que determinada criação é difícil, mas a clara postura técnico-pianística torna-a de rápida adaptação às mãos. Dir-seia, igualmente, que os andamentos rápidos freqüentados por Mignone estão muitas vezes no limiar da velocidade, mas são realizáveis "à l'aise", graças à maneira pela qual o compositor escreve, dispondo as mãos não impossivelmente. Essa adaptação instrumental torna o compositor um mestre em desenhos técnico-pianísticos típicos, polimorfos, mas essencialmente individualizados e que percorrerão as várias fases da existência criativa de Mignone.

Acrescente-se que o compositor fora pianista transcendente - apesar do pouco espaço que reservava ao estudo de piano, após o compositor instalado definitivamente - e a sua consciência coletiva o fazia compreender generosamente todos os estágios da pianística, o que resulta numa vasta produção cartesianamente construída que, se montada a nível de dificuldades, partirá da mais elementar elaboração digital, à transcendência extrema.

Percorrendo-se a extensa obra pianística de Francisco Mignone, observa-se que se está diante de mais de sete décadas de freqüência à criação dirigida. Determinados gêneros são preferenciais, como a Valsa e o Choro, o que, de certa maneira, apenas dimensiona as incursões em gêneros herméticos como as Sonatas, Prelúdios, Estudos etc.

Na produção para piano de Mignone, podem-se perceber correntes básicas, influenciadoras da criação. Primeiramente, uma vertente cosmopolita, resultado da ascendência italiana, repertório europeu praticado no Brasil, estudo realizado na península. Estes quesitos, filtrados, determinariam a criação de obras com princípios europeizantes tanto na textura musical como na própria titulação. Poder-se-ia dizer que a Itália, França, Espanha e Rússia são países que marcam Mignone. Nas Sonatas, 
Prelúdios, Estudos, Concerto e obras isoladas, segmentos extensos evidenciam o caminho cosmopolita conhecido pelo compositor. O geral apreendido não deixa de ter individualidades. Chopin, Liszt, Moussorgsky, Albeniz, De Falla, Stravinsky, Ravel e sobremaneira Debussy. são compositores que Mignone admira.

Uma segunda corrente tem raízes nacionais urbanas, ou folclórico-campesinas. As Valsas de Esquina, Valsas Choros e as Valsas Brasileiras pertenceriam basicamente ao citadino, enquanto que as Lendas Sertanejas, Dança dos Botocudos, Congada, Cateretê situar-se-iam num compartimento fronteiriço mais amplo. Assim mesmo, esse "amplo" difere do compartimento do nacional grandioso encontrável na destinação orquestral, quando conteúdos étnicos - indígeno, africano e europeu - se mesclam e se apresentam mais retumbantemente reforçados.

O piano vem a ser, quando da utilização do nacional-urbano, a visão mais intimista, o aparente capitis diminutio em comparação com a exuberância orquestral. Torna-se o piano o recanto mais buscado, pois é o possibilitador desta vazão mais íntima.

A obra para piano de Mignone é extensa e diversificada. Os vários "approaches" multifacetados que, em parte, desconcertam o analista, fazem parte de constante indagaçấo. Excetuando-se as várias produções sob o pseudônimo de Chico Bororó, verifica-se que Mignone exercita com competência e naturalidade as técnicas composicionais aprendidas e as conhecidas através da curiosidade. Tonalidade, modalidade, atonalidade, politonalidade e outras técnicas lhe são familiares e é sobremaneira em específicos gêneros praticados que Mignone adequa as diversas orientações conhecidas.

A relação eminentemente urbana o leva à tonalidade plena e à modalidade. As Valsas de Esquina, as Valsas Brasileiras, as Valsas Choros presas a reminiscências saudosistas de tempos de juventude fixam-se na tradição escritural. Estudos, Prelúdios, Sonatas e Sonatinas estabelecem, pela própria destinação mais hermética, a possibilidade da pesquisa mais diversificada. É quando Mignone incursiona em técnicas mais contemporâneas, sempre absolutamente "à l'aise". Escreveria:

Nada me assusta e aceito qualquer empreitada desde que possa realizar música. $\mathrm{O}$ importante para mim é a contribuição que penso dar às minhas obras. Posso escrever uma peça em Dó-maior ou menor, sem dor nem pejo, assim como elaborar conceitos de música tradicional, impressionista, expressionista, dodecafônica, serial, cromática, atonal, bitonal, politonal e quiçá, se me der na telha, de vanguarda com toques concretos, eletrônicos ou desfazedores de multiplicadas faixas sonoras. ${ }^{3}$

O presente ensaio não visa as diversas análises estruturais da produção pianística de Francisco Mignone. Contudo, dois aspectos básicos são abordados, após a visão sucinta da obra completa sob a trilha cronológica: código técnicopianístico e o timbre como busca clara no pensamento do autor.

A produção de Francisco Mignone original para piano solo nasce oficialmente em 1912, com a Danse du paysan, conservada em ms., onde até o título é francês. Até 1923, Mignone se atém a uma visão erudita ligada às fontes curopéias, ou então, a fim de premiação, à música urbana praticada em São Paulo e no Rio de Janeiro. Manon (valsa) e Não se impressione (tango), ambas de 1914, obtêm menção honrosa no I Concurso Musical organizado pela Casa Levy e que recebia o patrocínio da revista A Cigarra. Nos próximos anos, escreverá Polonaise e Minueto (1915 - ms.); Marcha dos Gnomos e Scherzo 
(1916 - ms.); Idílio Campestre (1919 - ms.); Minueto e Congada (1921), transcritas da ópera "O contratador de diamantes", sendo que a última tem freqüentado o repertório dos pianistas desde a sua versão, graças à sua pulsação rítmica afro-brasileira percutida marcante e ao todo voltado à feérica intensidade, atributos estes que fizeram com que Mignone a considerasse o "achado" da ópera; $2^{\circ}$ Minueto (1922); Égloga (1923 - ms.); Noturno Barcarola (1923 - ms.). De 1923 a 1941, Mignone escreverá dez Lendas Sertanejas. Nas mesmas, alguns ingredientes que caracterizam o nacional, como o ritmo, interválica de terça indicadora do cantar do homem do campo regional etc. Frise-se: as Lendas Sertanejas estão mais próximas, nesse longo período de suas gestações, de um "nacional" imposto pela necessidade de ser nacional do que do urbano espontâneo característico de criações específicas.

A Bacanal de Elfos é de 1926 e o Maxixe, de 1927, notando-se, ainda, a marcante presença cosmopolita atritando-se com a doravante sempre crescente existência do nacional, sobremaneira urbano, na produção pianística.

Em 1929, Mignone compõe a Primeira Fantasia Brasileira para piano e orquestra, que teve em Mário de Andrade um incentivador quanto a caminhos nacionalistas trilhados pelo compositor:

Nessa orientação conceptiva, em que a nacionalidade não se desvirtua pela preocupação do universal, é que está o lado por onde Francisco Mignone poderá nos dar obras valiosas e fecundas a sua personalidade. ${ }^{4}$

Nesta Primeira Fantasia e nas três que lhe seguirão (1931-34-36), Mignone utiliza, após filtração consciente, o amálgama de concepções européias e nacionais, e nelas a rítmica brasileira como um todo é decisiva. A posição de Mário de Andrade - que se tornaria um dos scus amigos mais fiéis -, contrária à italianizante postura de Mignone, em parte surtira efeitos. As Fantasias, concepções livres dessa nova postura consciente nacional, não encobrem, contudo, um conteúdo europeizante detectável: o melodismo pleno, atávico. Ele mesmo, considerando a facilidade criativomelódica, observaria: "(...) devo controlar a minha qualidade melódica, de maneira a não cair no banal ou no demasiado fácil". ${ }^{5}$ As Fantasias, em sendo debordantes de fácil comunicação rítmica brasileira e melódica ítalo-brasileira, são plenas de transcendência transparente pianística e de participação orquestral de rara adequação. Firmava-se Mignone, em 1934, entre os mais significativos criadores do gênero piano e orquestra no Brasil.

Microbinho e as Quatro peças brasileiras: Maroca, Maxixando, Nazareth e Toada são de 1930. A visão urbana se delineia com maior clareza. O tributo a Ernesto Nazareth, o pianista-compositor essencialmente urbano, será doravante reiteradas vezes citado. Compreende-se: o modelo que é parte de si mesmo, reencontrado e sempre renovado, necessidade em 1930 e nas décadas posteriores de citação nominal. Compreensão de hierarquia cronológica? Pode ser. A aproximação em relação a Nazareth, em compartimento específico e bem delineado, dá-se nas fronteiras do urbano, compreenda-se, não o mesmo das Valsas de Esquina.

Para Mignone, a virtuosidade the é absolutamente natural: 
dade, de maneira que ela seja lógica e não derrame em efeitos demasiadamente conhecidos e estereotipados. ${ }^{6}$

Virtuosidade natural é conseqüência de aptidão pianística natural. O "controlar essa virtuosidade", que pode ser composicional ou interpretativa, é dar conteúdo a fórmulas que podem resvalar na superficialidade. Não foram poucos os compositores que, escrevendo virtuosisticamente, permaneceram nitidamente virtuosísticos. O controle dessa virtuosidade, que tende facilmente ao supérfluo, é a penetração no território transcendente, quando a virtuosidade controlada, estudada, organizada ultrapassa as fronteiras levianas e dimensiona a própria essência da trama da textura musical.

Em 1931, Mignone compõe uma de suas principais criações para piano, os Seis Estudos Transcendentais. Dedicados a Guiomar Novaes, a coletânea traz no cerne uma quase constante - quando o vislumbre é o nacional de fronteiras mais extensas - relacionada ao ultrapassar o menos complexo técnico-pianístico existente no piano de destinação urbana. No futuro, o transcendente estará ligado muitas vezes ao abstrato, e, nestas circunstâncias, o conceito é parte do universalismo. Os Seis Estudos Transcendentais carregam consigo uma carga emocional-descritiva através de titulação induzidora: Velho Tema, Morte de Anhangüera, A Voz da Floresta, No Coqueiral, A Menina dos Cabelos Cor de Graúna, Saci. Volta-se Mignone ao histórico, ao lendário, ao nacional. $\mathrm{O}$ conteúdo pianístico é abrangente. A ausência de barra de compassos do Velho Tema (eslavo?) dimensiona a liberdade de flutuação de andamento dessa página grandiosa. Em A Morte de Anhangüera, o autor explora uma de suas mais marcantes inclinações, a busca timbrística, que distintamente estará explorada em A Voz da Floresta. O Coqueiral contém secçăo que é homenagem nominal ao seu claro modelo timbrístico, Claude Debussy, em compartimento caro ao compositor francês, as baixas intensidades banhando notas que se destacam em passagens fluidamente arpejadas. A Menina dos Cabelos Cor de Graúna, logo após a homenagem a Debussy, não seria uma versão poético-tropical à La fille aux cheveux de lin do autor francês? Sob outro aspecto, esse "tropical" não teria conotaçōes hispânicas, pois sensível é a proximidade de Estudo com La serenade interrompue, prelúdio que sucede imediatamente ao La fille?.. Tanto Debussy como Mignone apresentam na La Serenade e no Estudo, respectivamente, este processo técnico-pianístico que lhes é extremamente familiar, as māos alternadas. Os desenhos em fusas rapidíssimas são típicos exemplos dessa visão pianística transparente, clara a Mignone. Esta estará presente em O Saci, onde o autor realiza conjunção de desenhos expostos pela mão direita e igualmente em mãos alternadas, e a transcendência maior volta-se à absoluta igualdade que deve transparecer.

Ainda de 1931, algumas pequenas peças: Miudinho, que teria transcrição para Quarteto de Cordas e Orquestra de Cordas no mesmo ano; Tanquinho (ms.); a muito frequientada Valsa Elegante, que no seu "élan" faz jus ao nome; Noche Granadina e El Retablo de Alcazar, captação extremamente adequada - poder-se-ia dizer, escrita por compositor hispânico - de reminiscências de periodo passado em Espanha entre 1927 e 1928; Valsa em Sol Maior; Cucumbizinho, cujo nome e o início da peça encobrem a problemática técnica diver- 
sificada e complexa, que se desenrola a seguir; Seguida para 3 Serenatas: Pierrot, Arlequim e Cornetinhas de Papelão, mantidas em ms.; Cateretê e a presença do marcante sincopado; Quebradinho, onde, ao estilo do "piano urbano", Mignone expõe como temática em caráter humorístico a célebre canção russa Olhos Negros.

Em 1932, Mignone compõe algumas criações de curto fôlego como Tango Brasileiro, Festa na Roça (ms.), Festa do Entrudo (ms.), Gavotta All Antica (ms.), Quando eu era pequenino, singela composição com norteamento didático. Frise-se: o dedilhado do autor, na edição Ricordi Brasileira, significa por parte do compositor a preocupação com o resultado da qualidade sonora dos vários elementos da textura musical. Serenata Humorística é peça bem jocosa de Mignone. Escrita em Fá maior, em andamento "allegretto saltellante" basicamente em "staccatto", apresenta na secção B em Si bemol canto popular exposto em intervalos de terças. A complexidade da peça reside na interpretação plena de flutuações de anđamento.

Os Seis Prelúdios, igualmente compostos em 1932, estão entre os principais trabalhos de Mignone para piano. Poder-se-ia considerá-los, apesar da brevidade dos mesmos, como síntese de muitos dos processos pianísticos encontrados em obras anteriores, assim como o marco de muitos desenhos que estaráo configurados em obras das décadas vindouras. Entre os principais ingredientes pianísticos: busca timbrística números II e IV; a concepção visando os acordes plenos números II, V e VI; o prazer pelo arpejo diferenciado número I, ou pelo acorde arpejado números III e VI; a superposição de planos sonoros número $\mathrm{V}$ e principalmente o número VI.

De 1933 a 1937, a produção para piano solo sofre redução c estará voltada, preferencialmente, a níveis básicos pianísticos. Em 1933, escreve peças infantis: Preludiozinho, Rondó dos pequenos misoneístas, Toada, Você não me pega, Cachorrinho está latindo; em 1934, Crianças brincando, com processo instrumental lembrando Polichinelo de Villa-Lobos; em 1935, uma singela Valsinha para principiantes; de 1936, Marvadinho. Dois anos após, um Puladinho.

Se as Lendas Sertanejas - visão nacional menos limitada fronteiriçamente - apresentam-se em criação cronológica bem descontinuada, o mesmo não se pode dizer das doze Valsas de Esquina, que se estendem de 1938 a 1943, sendo que as primeiras cinco datam de 1938, três de 1940 e quatro de 1943.

A Valsa, gênero que se abre em leque desde o Brasil Imperial, para várias estilizações, é para Mignone o resultado de todo um acervo adquirido na cidade e voltado à improvisação, à serenata, a descontração, à nostalgia. Em sua mocidade, o jovem Francisco percorria com amigos seresteiros determinadas ruas paulistanas, improvisando melodias em instrumento "genético", a flauta, e cedo apreende o fascínio e os segredos do conteúdo noturno voltado à serenata, à musa, despertando através do sonoro a possibilidade do enlevo. A acompanhá-lo alguns instrumentistas, entre estes o violonista, pedra angular na compreensão do urbano musical de.Mignone. A serenata vem a ser a referência inconsciente que perdurará durante a longa existência do compositor, e nela a improvisação é determinante. 
ro-natural-improvisado - mas finamente elaborado - se fez na produção pianística brasileira. A existência da graça, do discurso em que o banal - que poderia ser fronteira trágica - não tem a menor guarida favorece para a coletânea como um todo, a assertiva de verdadeiras obras-primas, de padrão da melhor qualidade universal. Meiodismo efusiante, acompanhamento tantas vezes "pontuado" lembrando o violão, toda essa música que se ouve como a mais agradável das improvisações é fruto de técnica segura. Contrastantes mas, paradoxalmente, homogêneas em majoritária forma ternária-simples, evidenciam estilo definido, detectável e claro, o que as torna insofismáveis criações do autor. As doze Valsas de Esquina permanecem, unitárias ou reunidas em pequenos grupos, como as mais freqüentadas pelos intérpretes, e, saliente-se, por Francisco Mignone durante décadas. A constância auditiva das obras teria sido o caminho definitivo que o levaria à linguagem redimensionada, em muitas oportunidades, nas Valsas Brasileiras e nas Valsas Choros.

Em 1939, Mignone escreve uma Modinha e uma atraente coletânea de conotação infantil: Caixinha de Brinquedos, constituída de sete peças: Dorme Bonequinha, Brinquedinho Japonês, Os dois gatinhos, A Boneca Doentinha, Dança Campestre, Travessuras do Mascarado, Briga de Borboletas.

O constante retorno em visão menos espontânea às raízes africanas faz Mignone transcrever para piano, do ballet Leilão, as peças: No Mercado de Escravos, Dança Sensual, Rituale Batuque. Isto em 1940, quando escreve igualmente uma Quase Modinha.

O ano de 1941 é qualitativamente importante. Surge a célebre Dança dos Botocudos, estilização de "conceito" indígena, peça de muito efeito. A Primeira Sonata é o marco unitário de criação de maior fôlego no piano solo de Mignone. Sonata, Prelúdio e Estudo fazem parte, para o autor, de um mesmo universo quanto à destinação. Se elementos nacionais estão presentes, é contudo o conteúdo abstrato mais amplo que, em existindo, torna-se possibilidade de, em obras similares futuras, sedimentar o compositor curioso de novas tendências presentes nas sonatas vindouras. Na Sonata número 1, Mignone se utiliza de um quadro técnico-pianístico amplo e que pode ser considerado como substancial detectação de seu código tecladístico característico: linhas arpejadas "fixas" e contínuas, notas repetidas, ostinatos (primeiro movimento), buscas timbrísticas (segundo movimento), paralelismos "assimétricos" (terceiro movimento), mãos alternadas (primeiro e terceiro movimentos), deslocamento métrico em secções definidas.

De 1942, uma pequena obra maiúscula, aparentemente fácil: Doçura de Manhãzinha Fresca, dedicada a Oneyda Alvarenga. Descritiva, a peça evolui em seu ritmo sincopado, com valores diferenciados, permanecendo dentro de uma atmosfera que em muito lembra concepções francesas ligadas ao sugestivo e à impressão. Do mesmo ano nascem: Modinha Imperial (ms.), transcrição; Paulistana (ms.).

Em plena Segunda Grande Guerra, 1943, Mignone compõe os Três Prelúdios sobre Temas Canadenses (ms.): Marianne s'en va-t-au moulin; Sainte Marguerite, veillez ma petite! e À la Claire Fontaine. Em manuscrito permanecem igualmente as contrastantes Minueto e Samba, escritas em 1944.

O ano de 1945 vê nascer duas pequenas e ventiladas peças: No fundo 
do meu quintal e $O$ Pobre e o Rico. A primeira, em sua forma $\mathrm{ABABA}$, é uma das mais freqüentadas obras do compositor, devendo a sua quase obrigatoriedade junto aos currículos oficiais dos Conservatórios para os cursos elementares, as propriedades temáticas de fácil comunicação, ao pianismo prático e aos contrastes rítmicos e de andamento. A segunda, sem ter tido a mesma guarida junto ao público, é igualmente peça de curto fôlego, apropriadamente técnica e percussiva.

Se as Valsas de Esquina significam, em parte, o resultado de captação auditivo-sensitiva-visual das décadas que as precederam, poder-se-ia dizer que tanto as Valsas Choros, igualmente em número de doze e que percorrem a produção do autor de 1946 a 1955, assim como as 24 Valsas Brasileiras, que se estendem de 1963 a 1984 (somente em 1979 brotam da pena de Mignone as de número 4 a 12 e, em 1984, as de número 13 a 24), contêm muitos dos ingredientes já traduzidos nas Valsas de Esquina. Se o idiomático se mantém nas obras posteriores, todavia, é nas criações cronológicas anteriores que uma determinada espontaneidade se define mais delineada. Observe-se, porém, que o clima intimista permanece e o estereótipo prender-se-á mais ao técnico-pianístico.

Em 1947 surgem pequenas peças isoladas, como Pequena Valsa de Esquina; Valsinha; Toccatina e o festejado Lundu, que, em forma de Rondó, rápida, digital, de pulsação nervosa, se tornaria uma das mais freqüentadas criações de Mignone.

De 1948, uma série inspirada em Monteiro Lobato, Narizinho, constando da mesma quatro expressivas miniaturas: Sonho de Emília, Sala do Trono, Pequeno Polegar e Narizinho Dança. Quando voltado ao lúdico infantil, Mignone capta, assim como o fizeram Moussorgsky e Debussy entre tantos outros, aspectos inerentes ao expressar direto das crianças. Este "approach" nem sempre significa que a obra é destinada ao piano mais elementar. A coletânea citada pressupōe um convívio de alguns anos do aluno com o instrumento.

Para Mignone, 1949 representa o exercício da forma Sonatina. Compõe quatro e há proximidade entre as mesmas. A captação de um piano menos virtuosístico, mas, por vezes, voltado ao sonoro amplo, é característica. Comparando-se às Sonatas, a linguagem se mostra mais despojada. A preocupação formal destas criações de inspiração abstrata torna o elemento nacional, quando evocado, menos natural do que nas composiçôes específicas. Sente-se, por outro lado, que a densidade de uma $3^{\text {a }}$. Sonatina, microuniverso de muitos problemas técnicos abordados pelo autor, a faz aproximar-se de conceitos de Ravel sobre a forma característica.

De 1950 a 1955, Francisco Mignone produz pouco para piano. Série de Valsas Choros e uma peça isolada, Angela tocando cravo.

Entre 1956 e 1958, duas produções significativas para piano e orquestra. Burlesca e Toccata, apesar da brevidade, é embasada em outro clima distante das Fantasias Brasileiras. Pouco freqüentada, mereceria uma retomada por parte das Sociedades de Concertos. Em 1958, Mignone compóe certamente a sua obra mais totalizante para piano, o seu único Concerto para o instrumento e orquestra. Dedicado a Arnaldo Estrella no ano de seu cinqüentenário, o Concerto é apresentado em primeira audição pelo dedicatário em 1959, no Teatro Municipal do Rio de Janeiro, tendo o autor à frente da Orquestra Sin- 
fônica Brasileira. Compreende-se que Francisco Mignone visa o músico abrangente, possivelmente o primeiro pianista brasileiro tecnicamente completo. Tal destinação se traduz na mais extensa e transcendente produção pianística do compositor, sendo, possivelmente, uma das mais significativas criações do gênero no continente. O código tecladístico de Mignone aqui se encontra dimensionado em sua totalidade. O amálgama piano e orquestra fá-lo se aproximar da fusão comunicativa entendida anteriormente por Rachmaninoff e Ravel. Por outro lado, elementos nacionais são adequadamente utilizados, sendo que o melodismo entusiasmado torna as temáticas desenvolvidas de fácil assimilação.

O lúdico infantil, não distante do didático, estará presente nas peças do caderno As Criancinhas de D. Liddy (ms.), escrito em 1959, referência ás alunas de sua primeira mulher, a musicista Liddy Chiafarelli. Desfilam: Palhacinhos, Equilibristas, Alegrias e Tristezas e Marcha Final. Verifica-se, entre o Concerto para piano do ano anterior e esta obra pueril, a versatilidade do autor, o saber dizer complexa e tenuemente. Do mesmo ano, a segunda versão de Paulistana, conservada em manuscrito.

Se as Valsas pertencem à constante improvisação "controlada" e a realidade com que Mignone as escreve traduz a comunicação direta, não havendo o questionamento escritural contemporâneo que poderia resultar em impasse para o gênero, as três últimas Sonatas traduzem o universo mais cerebral do compositor e determinados ingredientes "orquestrais" são tratados de maneira brilhante e burilada. Vinte e um anos separam a Primeira Sonata da segunda, sendo que a terceira é de 1964 e a última de 1967. Percebe-se que em todas as três últimas, Mignone, sem abandonar determinados princípios do seu acervo criativo instrumental, estará mais próximo de um pianismo percutante e a timbrística se mostrará mais enriquecida. Há um prazer do autor, nestas produções, pela resultante sonora como um todo e sobremaneira pela presença de uma pianística onde as formulas improvisadas se submetem à rígida elaboração cerebral.

Há em Mignone claro norteamento quanto aos gêneros. Se nas Valsas, Choros e outras produções afins, o autor se utiliza de procedimentos técnicos menos enciclopédicos e onde muitas vezes a virtuosidade é virtuosidade, nas obras de inclinações mais herméticas há maior abrangência no complexo código do autor. O universo não evocativo de Mignone é um amplo laboratório, onde a espontaneidade é transitória, mas o "cerebralismo" não artificial. E as

Sonatas configurariam essa preocupaçāo por parte do autor.

Verifica-se, no limiar da terceira idade, mais insistentemente, a penetração na faixa destinada a níveis didáticos. Possivelmente visando a acessibilidade do gênero Valsa de Esquina, compõe em 1964 Seis Pequenas Valsas de Esquina: Cantando, Doloroso e Agitado, Vivo, Seresteiro, Delicado c Triste. Guardam no cerne características multum in minimo das Valsas criadas décadas atrás. Do mesmo ano são as Seis Pecinhas para Piano: A fadinha canta, Valsinha, A Bonequinha dorme, Os Soldadinhos Passam, Os Cavalinhos do Carrossel e O Pequeno Mozart Toca.

Em 1968, mais Quatro Peças Infantis, entre elas: Primeira Valsinha, Dança do Arlequim, e igualmente para piano básico, a lírica E O Piano Canta Também.

Contrastando com tudo o que anteriormente escreveu, mas nāo desprezando o código técnico-pianístico básico, Mignone, em linguagem contemporânca, eviden- 
cia domínio escritural adquirido em parte pela curiosidade do sempre conhecer e escreve, em 1971-72, os 6 1/2 Prelúdios. A incrível brevidade dos mesmos - o de maior número de compassos é o de número IV com 16; e o menor, o de número $1 / 2$, com 6 apenas - dá mostra de extrema concisão dos processos elaborados. Estes microprelúdios são profundamente contrastantes tanto na trama da textura musical como nas referências dinâmicas. Mais do que a penetração em linguagem contemporânea evidente, os $61 / 2$ Prelúdios correspondem a profundo sentido timbrístico e poder-se-ia considerá-los como depositários de igualmente uma segunda titulação: Estudos para intensidades. Acordes, clusters em várias tipificações diferenciadas visando a resultante sonora, planos distintamente acentuados, centros tonais transparentes, todo o acervo apresentado visa igualmente a flutuação sonora, as graduais ascensões ou diminuição das intensidades, ou o abrupto.

Sugestivos são os ciclos escritos em 1976 e destinados ao nível médio. Titulação e textura musical têm a ver com o descritivo. Herança clavecinística, Mignone busca imitar sons, intenções, ritmos e movimentos. Na primeira série denominada Peças Fáceis tem-se: A Coruja e a Águia; A Menina Leiteira; A Mosca e a Formiga; O Corvo e o Pavão; O Leäo que não era Leão; O Velho, o Menino e o Burro; Os Barqueiros Passam; Os Pombos. Da segunda série: Cinco Peças para Piano: a Orfâzinha; Formiguinhas Trabalhando; A Rã e o Sapo; Hoje não tem aula; O Gato e o Rato.

No ano de 1977, novamente Ernesto Nazareth é lembrado em atributos sensíveis ao pianista-compositor urbano: espontaneidade, nostálgico chopiniano, brejeirice e humor. Os Quatro Choros: Brejeiro, Gracioso e Moderato, Com Alegria e Assai Vivo inspiram-se em Tangos de Nazareth: Escovado, Labirinto, Duvidoso c FonFon. Brejeiro, retrabalhado, foi dedicado a Nelson Freire, permanecendo em ms. Ratificando a admiração, Mignone compõe no mesmo ano Nazarethiana, contando da mesma série cinco peças para piano: Com Entusiasmo, Romântico, Scherzando, Molto Allegro, Allegro.

Em 1979, Francisco Mignone compõe nove Valsas Brasileiras e uma peça na qual pretendeu homenagear Portugal. Trata-se de Adamastor - $O$ Gigante das Tempestades, inspirado nos Lusíadas, de Camões. Plena de uma linguagem mais contemporânea, empregando clusters, notas rápidas $\mathrm{cm}$ cluster liqucfeitos, dinâmicas extremas e um pianismo abrangente, a obra é contraste marcante comparada às ternas Valsas Brasileiras.

O Improviso Romântico é de 1980, assim como Il Neige Encore, com a qual, dentro do espírito de Il Neige! de Henrique Oswald (1852-1931), Mignone procurou homenagear o colega desaparecido, pouco antes do cinqüentenário da morte deste. $\mathrm{Na}$ peça "tombeau" o autor buscou proximidade com o modelo inspirador e parte do clima, assim como determinadas evoluções do acompanhamento sugerem uma continuação da criação de Henrique Oswald.

Em 1982 e 1983, apenas duas obras: a segunda versão da Barcarola (ms.) de 1925 e uma Valsa, respectivamente.

O ano de 1984 é, comparando-se à atividade criadora dos anos anteriores, de grande fecundidade. Não seria este feérico retorno ao piano, pouco antes da morte, a preferência marcante pelo instrumento confidencial? Escreve doze Valsas Brasileiras; Seguida, da qual constam: Temperando, Outra Lenda Sertaneja, Beliscando 
Forte, Valsa que não é de Esquina, Batuque Batucado. ${ }^{7}$ Nesta série Mignone demonstra uma textura que traduz, preferencialmente, fino humor.

Diferenciando a motivação criadora, o autor, sensibilizando-se pelo drama de uma criança que, estudante de piano, sofrera um acidente com a mão direita, escreve as inusitadas Quatorze Pecinhas Para a Mão Esquerda: Modinha Dramática, Sapeca (desenvolta), Scherzando (brincadeira), Jangada, Gavotta, Minuetto, Deslizando, Canção, Cantiga de Ninar, Brincalhão, Valsa, Escorregando sem Parar, Coral, Sonhando.

Se em Seguida há jocosidade, o mesmo se pode dizer dos Treze Choros Sem Conseqüência, igualmente de 1984, em que Mignone explora novamente o urbano, reverencia uma última vez Nazareth, despoja-se de vários ingredientes que existem em obras anteriores e... se diverte. Desfilam: Deixando-se ir; Tereteté, Tereteté, Tereteté; A Moda de Viola; Capadócio; Deixando-se levar; Encontro tão Amável; Agressivo; No Terreiro; Este é bem Nazareth; Cabeludo; Chorinho Mesmo; Dá Vontade de Tocar; Namorados.

Em 1985, já enfermo do mal que o abateria, escreve duas obras Yá e finalizando toda a extensa produção, uma das mais expressivas e singelas peças do autor, síntese abreviadíssima do gênero mais profusamente explorado, a Valsa. A Última Valsa, pequena e despretensiosa criação, contém no todo da construção ingredientes que sugerem profunda nostalgia.

Mignone praticaria com a mulher Maria Josephina, pianista dedicatária de tantas obras do autor e a maior divulgadora das obras do marido, um vasto repertório a dois pianos, sobremaneira de produções transcritas e que viriam lucidamente enriquecer o repertório brasileiro do gênero. Entre estas transcrições contam-se Valsas de Esquina, Congada, Lundu e tantas outras. Frise-se que em determinadas obras de Nazareth, entre as quais Apanhei-te Cavaquinho, Faceira, Confidências, Odeon, Sarambeque, o primeiro piano realiza a partitura de Nazareth e o segundo é criação de Mignone. $O$ resultado é extremamente curioso, demonstrando invulgar perícia do autor da adaptação. Por outro lado, se as obras de Nazareth são independentes e se prestaram ao "enxerto", este é igualmente independente e, se executado isoladamente, torna-se obra original que vive de sua própria experiência divertida. É o sempre prazer em criar, axioma característico de Mignone.

Considere-se como de real importância para a compreensão do código técnico-pianístico de Mignone os Exercícios Tira-Prosa, escritos entre 1980-85, nos quais o compositor-pianista capta muitos dos problemas a serem resolvidos pelos instrumentistas. Ao todo são 48 exercícios com variantes, os quais Mignone realizava com cônscia tranqüilidade.

Dois aspectos básicos relacionados à escrita de Mignone para piano sugerem uma fixação maior: parte do código técnico-pianístico - o que possibilita a visão do todo - e determinada volúpia pelo timbre.

O escrever bem para o piano, de maneira absolutamente natural, não é regra entre os compositores que perduraram pela qualidade da escrita. Mozart, Schubert, Schumann, Chopin, Liszt, Debussy, Rachmaninoff, Ravel, entre outros, revelam pianismo natural quando a transcendência da virtuosidade será pertinente à arguta logicidade dos desenhos que se adaptam às mãos com rara objetividade.

Em termos brasileiros, creio que Henrique Oswald, Francisco Mignone e Almeida Prado possuem essa naturalidade pianística. Atenha-se: os três familiarizaram- 
se com o instrumento, sendo que os dois primeiros foram bons pianistas, e o terceiro, em o sendo, teve cste dado - não como um imperativo - como o corroborar o conhecimento de todos os segredos da técnica pianística.

Em que consiste essa naturalidade? Necessariamente do ser um pianista? O compor de maneira natural não significa a obrigatoriedade do ser um pianista. Pode ajudar e muito o convívio instrumental, e mais ainda a execução pública do pianista-compositor, o palco sendo o laboratório consciente ou não de muitas fórmulas que se estabelecem através da prática intérprete-público. Naturalidade não é sinônimo de qualidade e, se os três compositores citados conseguiram unir ambas as qualificações, mais apropriadamente a produção será pianística. Aí estão Alberto Nepomuceno, Glauco Velasques, Villa-Lobos, Camargo Guarnieri, entre outros, a permanecerem através de excelentes ingredientes qualitativos da textura musical, superiores à naturalidade essencialmente pianística.

Em Mignone tem-se a obra pianística multifacetada, que por vezes desconcerta o analista. A facilidade - temida pelo autor, quando não controlada - fế-lo incursionar por segmentos onde a trama da textura musical sofre abruptas transformações. Se, para a maioria dos compositores que escreveram para teclado até meados deste século, a evolução escritural segue caminhos sem retorno, detectáveis, onde há o acervo acumulado dos processos individual e coletivo - em se tratando do captado de outros autores -, em Mignone sentem-se avanços e recuos. Ambos fazem parte da sua verdade. O conhecimento das inúmeras técnicas composicionais tornamno um curioso de gênio que, após a experiência finda, torna o recuo às fontes urbanas - onde a textura se mostrará mais presa à tradição - uma quase necessidade.

Esta diversidade do pensar musical poder-se-ia pormenorizar sob os vários aspectos analíticos das estruturas musicais. Forma, harmonia e tantos caminhos afins. Chama, contudo, a atenção a constância - quando das incursões de Mignone a tendências heterogêneas - dessa irreversível manutenção de seu código técnico-pianístico e de funda penetração no universo timbrístico. O primeiro tem origem na improvisação, o segundo embasa-se na qualidade do audicionar, na incessante preocupação pela resultante sonora. O código vem de dentro para fora espontaneamente, o timbre, após seletiva filtração interior, recodificado, verterá pela mesma trilha.

A improvisação geraria, por força da repetição constantemente renovada, a fórmula específica. Esta, técnico-pianística, é diversificada, transparente, adaptável ao caminhar da textura, mas sempre identificável. A cilação de algumas dessas fórmulas serve para compreender-se setor importante do universo tecladístico de Mignone. Em sendo latentes, existindo a priori da criação, fixam-se originariamente no pré-instante do acontecido e, ligciramente transformadas ou näo, transmutam-se para a criação pautada. Registradas, elas passarão, cumulativamente através da extensa produção, a formar o estilo técnico-pianístico, a constituir um código especial.

Há fórmulas que têm maior ou menor norteamento ligado à improvisação. $O$ compositor, em passagens preferencialmente rápidas, utiliza-se de determinados elementos da linguagem pianística que lhe são rotineiros na criação espontânea c que, enquadrados nas fronteiras formais da obra construída, estarão mais diversamente elaborados. Esta diversidade, variação de embrião "motívico", é um dos segredos do compositor.

Entre estas fórmulas originárias da improvisaçäo, precisem-se algumas que, primordiais ou intertexturais, percorrem a produção de Mignone. Poder-se-ia sempre 
perguntar que fórmulas em geral estão presentes em obras de outros autores. Contudo, é a freqüiência transparente na especificidade, em criações por vezes antagônicas, que individualizam o código técnico-pianístico dos vários autores.

Há uma célula de efeito auditivo aparentemente mais denso do que a notação na partitura, basicamente constituída de duas ou três notas seguidas ou precedidas de uma nota apenas. Em seu estado elementar tem-se (v. exemplo 1):

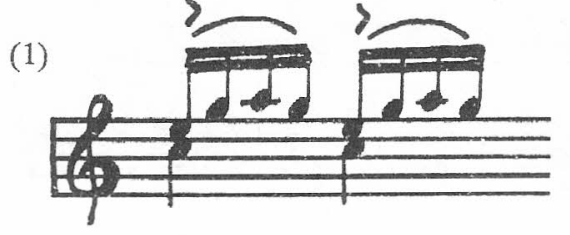

executado apenas por uma das mãos. Ampliando-se o quadro, é encontrável na obra para piano de Mignone este desfilar de notas duplas, que pode ter interválica variada: 2a., 3a., 4a., 5a., 6a., 7a. ou 8a., sendo que por vezes, o compositor introduz uma terceira nota formando uma tríade, deixando nos casos citados a nota subseqüente não preenchida pela nota dupla ou então a tríade. Esse processo, exaustivamente empregado por Mignone, dá, quando a passagem é rápida, a possibilidade de ser dominada mais comodamente por uma camada mais extensa de pianistas e auditivamente traduz a sensação das notas duplas executadas sem trégua. Em movimento lento, é analógico.

Alguns exemplos encontrados na Congada:
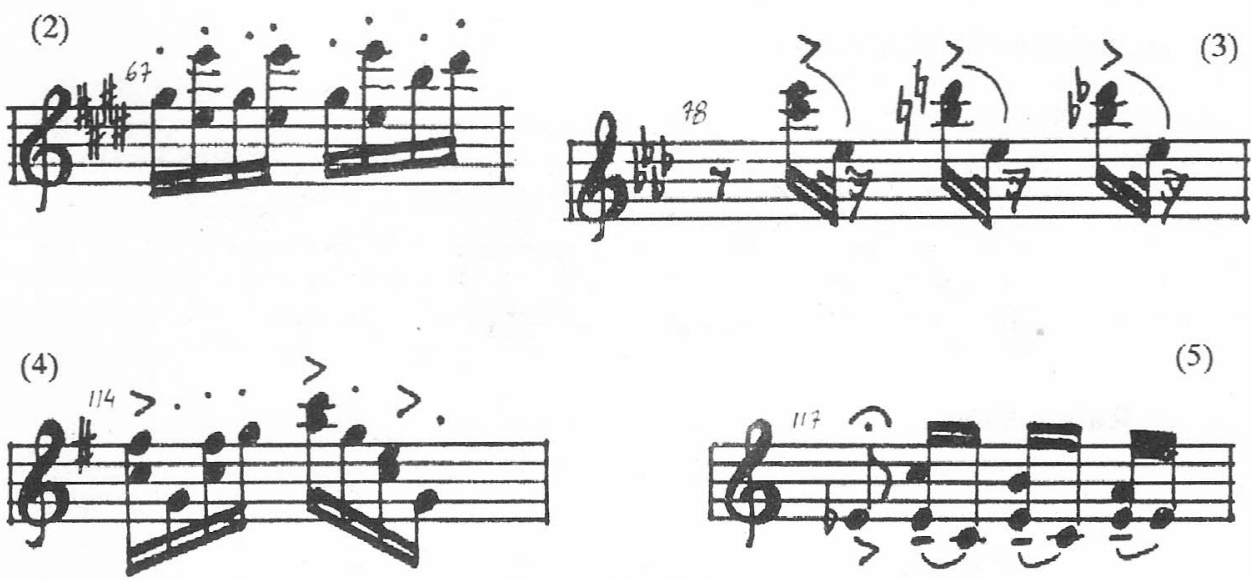

(5)

Outros exemplos em El Retablo del Alcazar

(6)

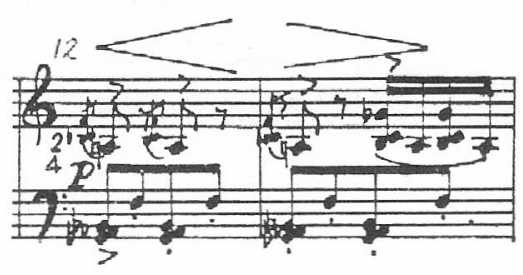


Cateretê

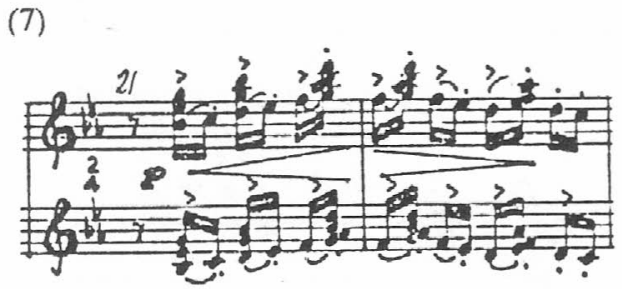

Doçura de Manhãzinha Fresca (xuexempla 8):

(8)

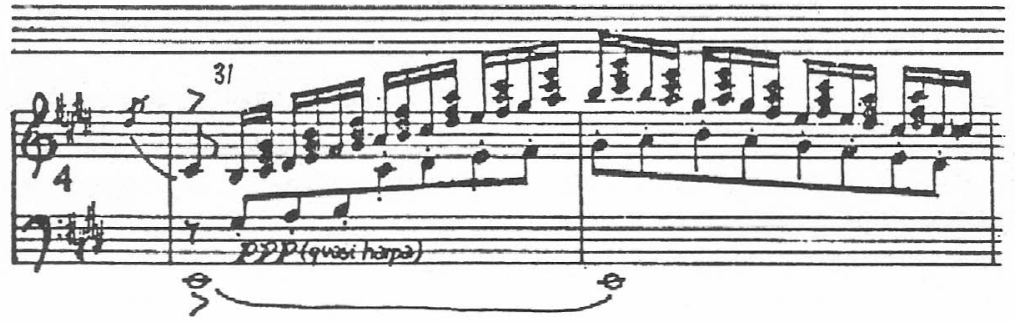

2a. Sonata - 39 Movimento

(9)

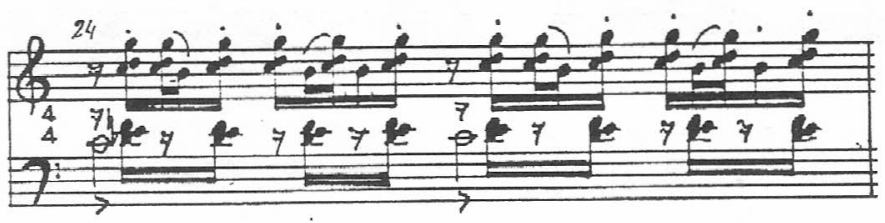

A Rã e o Sapo

(10)

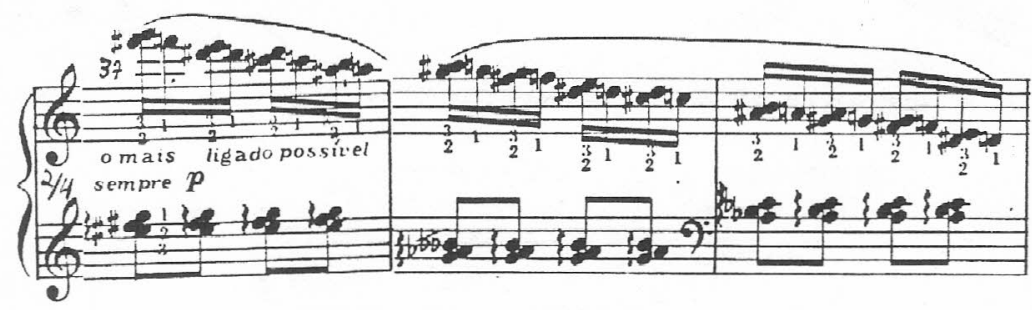




\section{Serenada Humorística}

Início

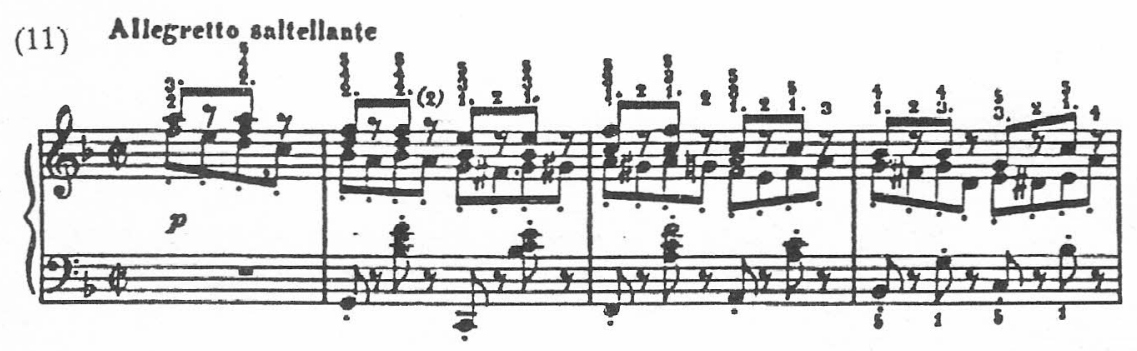

Da improvisação vem o enorme emprego que Mignone sabe tirar da prática das mãos alternadas, que já era largamente utilizada desde os clavecinistas. Contudo, é entre os românticos e franceses ligados à sugestão e à impressão que esse processo recebe o conteúdo fluido que lhe é peculiar, sobremaneira quando as mâos alternadas percorrem o teclado em sua extensão. Da elementar utilização de nota após nota executada pelas mãos alternadamente encontrável em O Gato e o Rato às configurações mais complexas, verifica-se que Mignone, partindo do efeito simples, descritivo até, busca na prolixidade de entrelaçamentos mais diversificados o grande efeito. Os desenhos freqüentados pelas mãos alternadamente servem: como ligação entre duas secções; integrante de uma secção determinada; visando o timbre; e como início e conclusão entusiasmados. Este alternar das mãos, que encontra no Concerto para piano e orquestra um vasto campo de praticidade - pense-se na massa orquestral corroborando as intensidades -, estabelece critérios quanto aos valores e aos ritmos, muitas vezes provocando o deslocamento métrico.

As formações deste alternar podem estar fixadas numa gama abrangente de divisão entre as mãos esquerda e direita. Citem-se entre outros: $1 / 1 ; 1 / 2 ; 1 / 3 ; 1 / 4 ; 2 / 3$; $2 / 4 ; 1 / 4 ; 3 / 3 ; 3 / 5 ; 1 / 5 ; 3 / 6 ; 4 / 3 ; 4 / 4 ; 4 / 6 ; 5 / 5 ;$ e o alternar de células verdadeiramente assimétricas constituídas de $7,8,9,12$ figuras, contra 2 ou 3 de uma das mãos. Considere-se que ao pianista sempre há a possibilidade de que tais movimentos alternados tenham figuras repartidas mais adequadamente à própria individualidade física. Em que resulta todo esse alternar característico em Mignone? Para o intérprete, uma maior descontração, e para o ouvinte, a sensação de transcendência. Este recurso alternado, insistentemente utilizado pelo autor, é menos o efeito fácil e mais a manifestação natural do improvisador nato que, com instantânea demonstração, percorre celeremente quase todo o teclado. Por outro lado, é por parte de Mignone a volúpia da velocidade transparente.

Outro recurso largamente empregado por Mignone é o da nota repetida. São inúmeras as produções em que o compositor grafa significativa e diversamente o procedimento. Simples ou visando uma inteiração mais abrangente, a nota repetida terá função importante na escrita pianística. No todo da criação, este recurso oriundo de improvisação e idiomaticamente abundante em Mignone, se apresenta igualmente como catalizador ritmico e a conseqüência poderá ser até fragmentada. Da fórmula existente na pré-criação à elaboração visando o resultado sonoro, Mignone sabe tirar proveito e a nota repetida poderá visar a inusitada extinção das sonoridades. 
No Estudo Transcendental $n^{\circ} 5$, a nota repetida corresponde a um preciso resultado timbrístico através da intermediação de notas insistentes em intervalo de 2a. maior ambientadas num amplo e distanciado impacto acordal (v. exemplo 12).

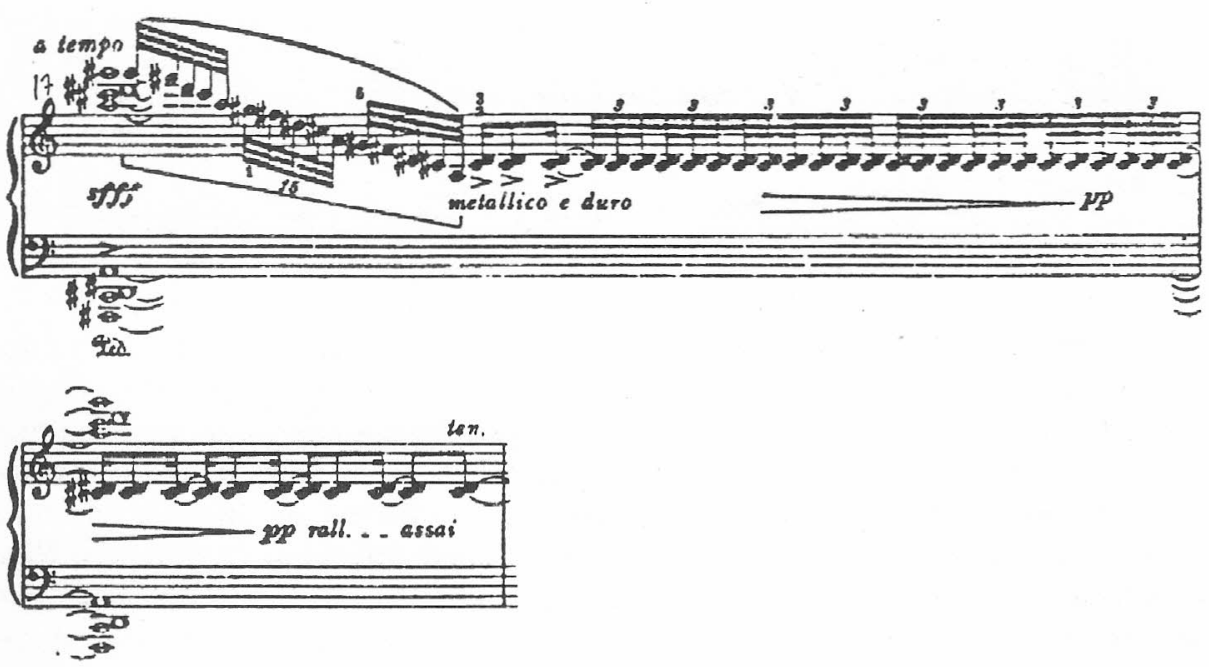

No Concerto Para Piano e Orquestra, na 4a. Sonata, Mignone emprega a nota repetida unitária ou simetricamente seguida de uma nota próxima, podendo o desenho ser estático ou desenvolvendo uma progressão:

Concerto para Piano e Orquestra (v. exemplo 13):

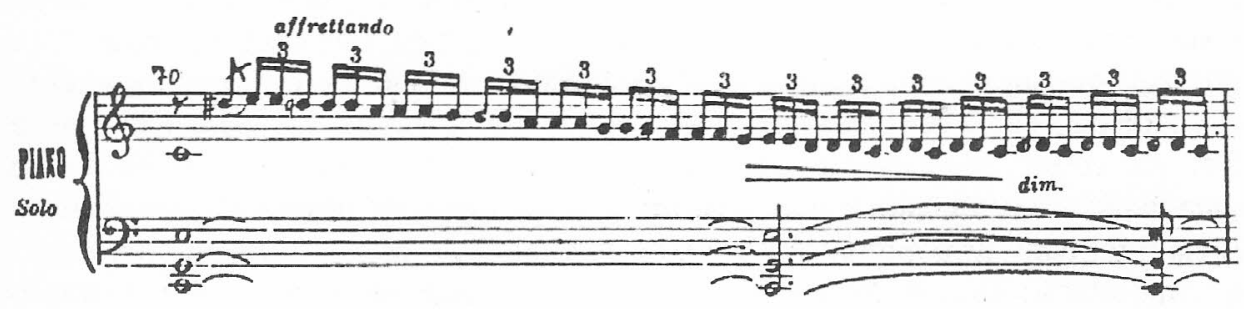

Compreende-se que, em Mignone, determinado aspecto técnico-pianístico, integrante de seu código, permanece sempre disponível para o emprego adequado que será tão mais transparente nas intenções finais quão mais próximo da pré-criação. Este seria um dos segredos de Mignone, que consegue, nas obras de cunho abstrato, preferencialmente, tornar o "improvisado" desenho elementar de seu idiomático mais hermético, mas sempre detectável, desvelando na complexidade a origem primeira.

O exemplo (13) citado acima, de um motivo oriundo da nota repetida, pode se expandir em repetiçōes de motivos, ostinatos tantas vezes. 
Chama a atenção na obra para piano de Mignone a quantidade de incisos e desenhos repetitivos que podem ser curtos ou mais desenvolvidos, e que sempre foram materiais de fácil manuseio para o autor no estado "estático" do exercício e que a serviço da criação se transfiguram em inúmeras combinações diferenciadas.

O $1^{\circ}$ tempo da 1 . Sonata apresenta três desses ostinatos bem delineados, sem contar as insistentes notas repetidas (v, exemplos 14, 15 e 16):

(14)

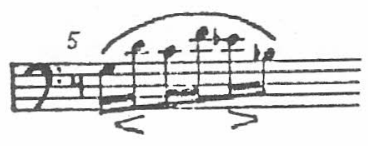

(15)

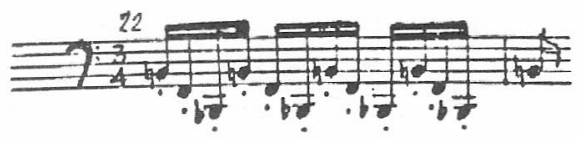

(16)

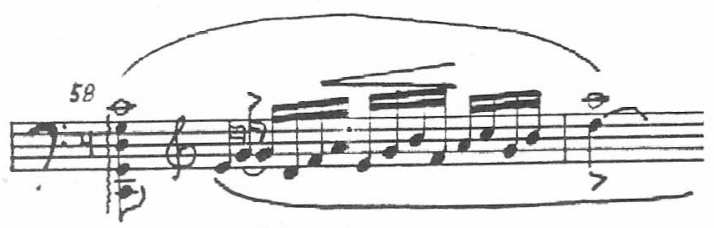

Puladinho repete fórmula da técnica dos cinco dedos que faz lembrar Les Tourbillons de Dandrieu. Em Noche Granadina há a presença de fórmulas próximas àquelas, mas estáticas.

No início do Estudo Transcendental $n^{\circ} 6$, tem-se um típico exemplo de improvisaçẫo-elaboração. Partindo de fórmula repetitiva em uma só mão, Mignone parte para o movimento alternado, retornando ao processo inicial, visando igualmente a qualidade sonora.

(17)
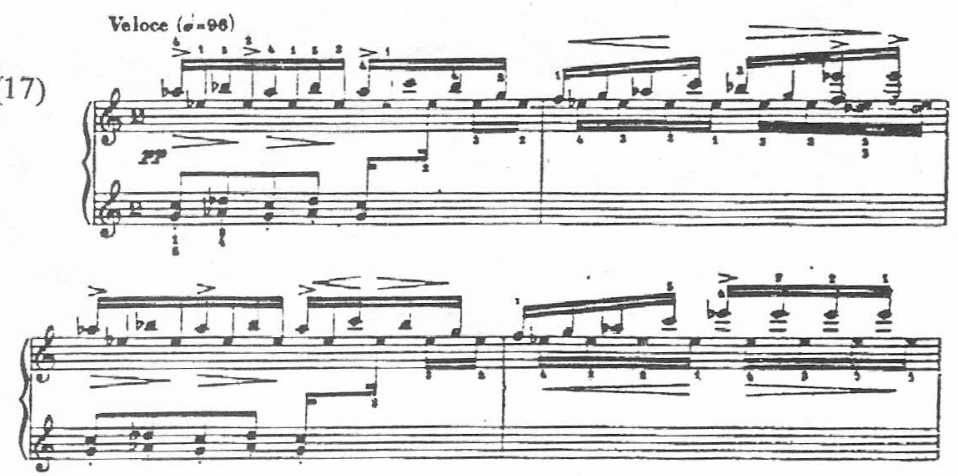
Pode-se considerar esse processo repetitivo estático ou em progressão como parte do idiomático, em Mignone. Desde as mais singelas peças, como Quando eu era Pequenino, até a complexa 3a. Sonata, os motivos repetitivos tornam-se quase "onipresentes", partindo de fórmulas baseadas em posicionamentos dos cinco dedos próximos, até distanciamentos maiores, o que sugere, em casos específicos, a constância da formula a serviço de movimentos acordais arpejados. Se, prioritariamente, Mignone realiza estes desenhos repetitivos na mão direita ou esquerda separadamente, por vezes, como reforço, estes desenhos podem, em paralelismo, estar presentes em ambas as mãos, havendo igualmente inúmeros exemplos em que o movimento das mãos torna-se assimétrico, guardando, contudo, o princípio de fórmulas insistentes, que sob o aspecto de extensão, pode constituir-se de apenas um inciso a uma frase, ambos repetitivos.

No $2^{\circ}$ andamento da $3 a$. Sonatina, tem-se um longo segmento com desenhos nas duas mãos, divergentes e em progressão (v. exemplo 18);

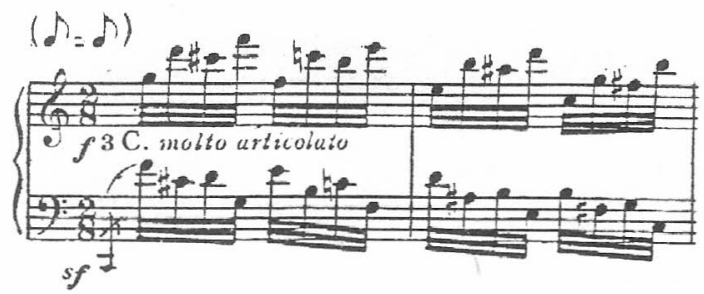

Em Paulistana tem-se duas fórmulas simétricas distintas nas duas mãos, constituídas de quatro fusas que, apesar da interválica diferenciada, executadas conjuntamente dão a impressão de unidade. O todo banhado por centro-tonal de Ré (v. exemplo 19):

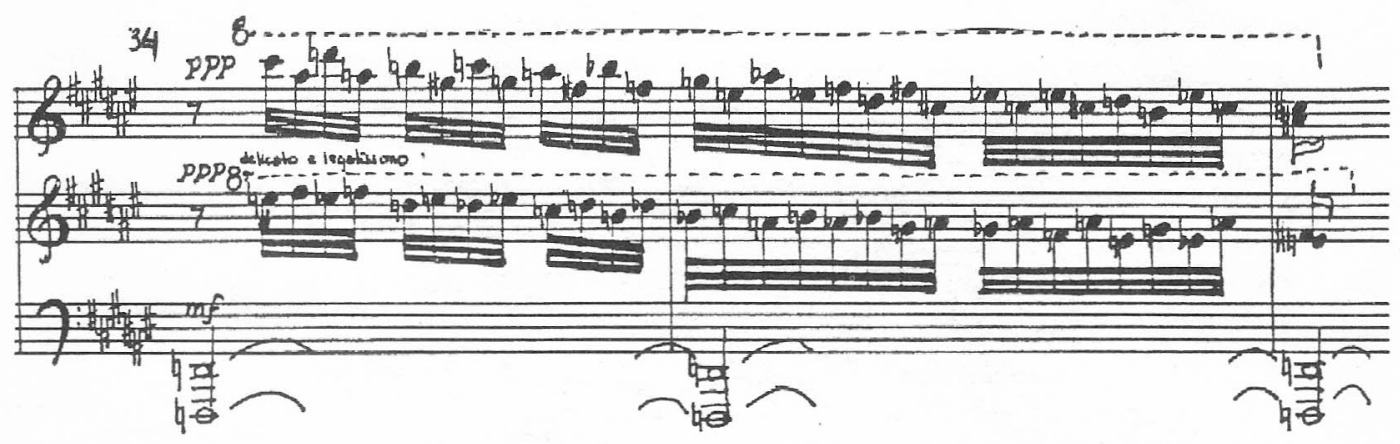


Um dos mais ventilados processos utilizados por Mignone é originário igualmente do ato de improvisar. Notas ornamentais e configurações de clusters, aquelas desde o início da criação e estas cada vez mais onipresentes nas produções posteriores, povoam a obra do compositor. ${ }^{8}$

Interessa verificar as funções que o autor dá às notas ornamentais, desde a "decorativa" à timbrística ou à descritiva, desta existindo exemplo significativo no "imitando o coaxar do sapo", em A Rã e o Sapo.

Saindo-se do aspecto descritivo do exemplo citado, nas 4 Sonatas e no Concerto para Piano, Mignone utiliza-se da formula constituída de notas ornamentais e a utilização destas visa vários desideratos: fins melódicos, timbrísticos, interpenetrando massas acordais extremas, participando da trama da textura musical - como um todo - quando estabelecidas em vários planos sonoros. As notas ornamentais rápidas, na maior parte das vezes e em tantos outros exemplos cômodas e expressivas, representam parte de uma característica inquisidora, nervosa, plena de curiosidade, envolvendo o compositor. Quem ouviu Mignone executando obra escrita ou divagando sobre um tema, deve ter retido - quando de peça urbana improvisada ou não - aquele movimento de mão "nonchalante" e descontraída ao realizar essas notas ornamentais que povoariam segmentos extensos de sua obra. É, pois, o insistir nesse elemento e a enorme gama de recursos que dele sabe tirar que evidenciam uma das versatilidades do compositor. Um típico exemplo de aplicação diferenciada pode ser sentida em Adamastor - O Gigante das Tempestades, em seu final, onde Mignone, com fins nitidamente timbrísticos, realiza essas "notas ornamentais" como continuação de clusters, só que as mesmas notas destes, repetitivas, tornar-se-ão clusters fluidos.

(20)
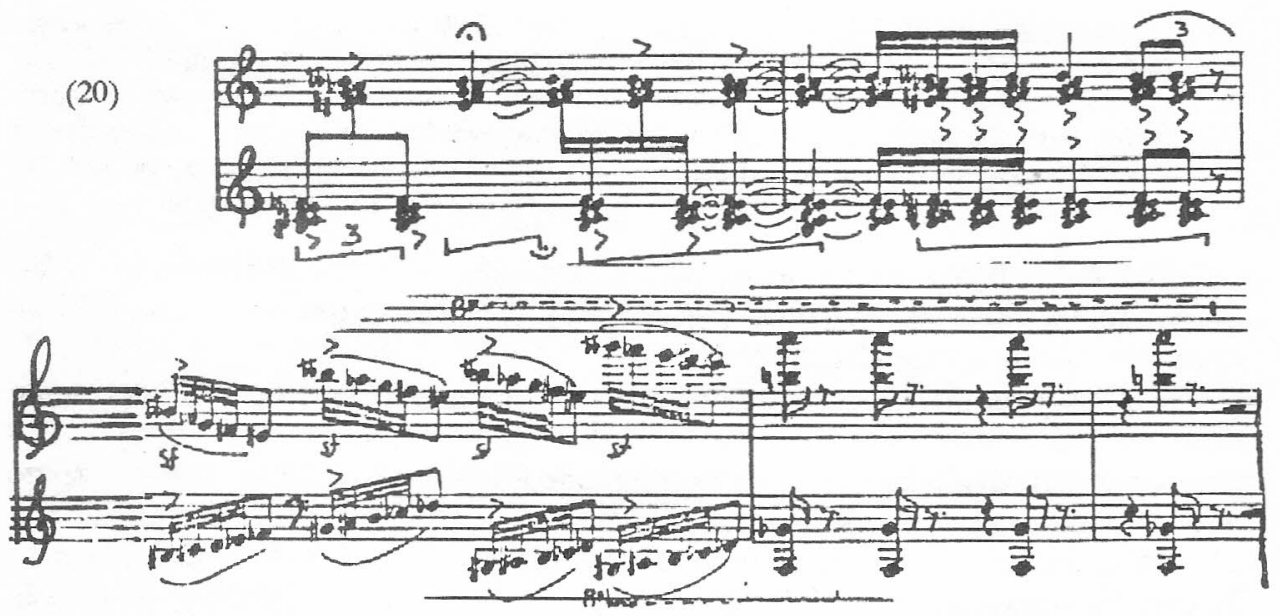
O 1/2 dos 6 1/2 Prelúdios apresenta duas caracterizações do cluster fluido: convergente e divergente em seus movimentos e em duas distintas grafias (v. exemplo 21).
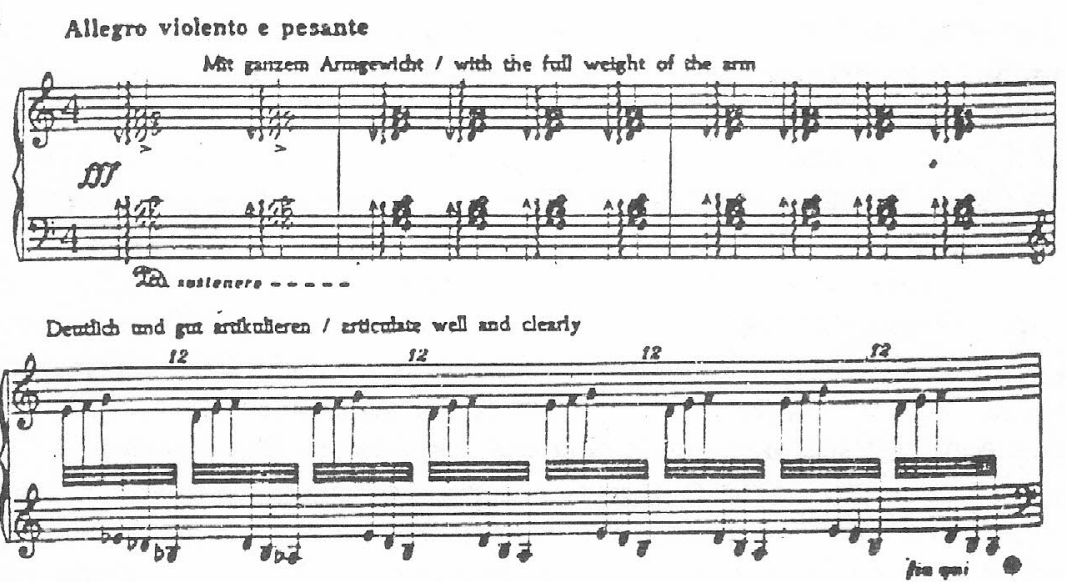

Aos exemplos citados e que fazem parte do universo técnico-pianistico do compositor, acrescentem-se alguns outros que podem ser originários da improvisação. A sucessão de acordes, estática ou em progressão; oitavas; abrangência onde acontecem vários planos sonoros em extensão territorial tecladística extensa; melodia interpenetrando massas acordais ou vice-versa; arpejos tipicamente desenvolvidos e que percorrem a extensão do piano.

Mignone sempre teve por Debussy admiração. Em A Parte do Anjo, observaria que

originalidade está na lógica da criação e se Debussy é feito de um terço de franceses (até de Massenet!), e uma terça parte de Moussorgsky, lhe bastou botar uma terça parte de Debussy na sua criação para ser original e chefe de escola! Então devo-me aproveitar de minha facilidade natural? Está claro que sim! Facilidade não é defeito, é uma das maiores qualidades para o artista. Só que é perigosa, e necessita controle fino. Só uma coisa deve repudiar a facilidade: 6 opor a ela a faculdade de pesquisa. ${ }^{9}$

Em outro ponto da narrativa, comenta: "Todos os grandes artistas de todas as artes foram enormes plagiários. O plágio só é condenável quando é feito com intenção de roubar o sucesso alheio". 10

Na absorção do código de outros autores, Mignone foi pródigo. O importante é que sempre resulta Mignone, o que o faz filtrador de processos que no final recebem a sua individualidade. O estilo de Mignone é característico e ao mesmo tempo versatilizado nestas captações conscientes.

Se o improviso estabelece o código técnico-pianístico - paradoxalmente mais patente nas obras não "improvisadas" - e se permite o consolidar cristalino da mensagem musical urbana da qual as Valsas de Esquina, os Choros e as Valsas Brasileiras, entre outras, são testemunhas, por outro lado, é a observação que fará Mignone se aproximar de modelos consolidados. E esta, distante do técnico-pianístico improvisado, resultaria na qualidade advinda do intelecto, pensada, ciência do som. 
Num todo da produção pianística do compositor, a admiração pelos russos, Moussorgsky em particular, é transparente. Ele mesmo não orquestraria os Quadros de uma Exposição? Como não pensar em Moussorgsky no início do Velho Tema, o primeiro dos 6 Estudos Transcendentais? Os inícios do Prelúdio $n^{\circ} 1$ dos 6 Prelúdios, das 2a. (distanciamento de dupla oitava) e 3a. Sonatina obedecem ao princípio "monódico".

Mignone é sucessão de muitas influências e ao mesmo tempo um dos mais originais compositores brasileiros. Se, por vezes, Mozart, Chopin, Liszt, Rachmaninoff, Albeniz, De Falla, Stravinsky, Bartók são reconhecíveis, ou então conteúdos operísticos e orquestrais de notáveis do século XIX passeiam camuflados em suas partituras, seria Debussy, possivelmente, a influência mais transparente. ${ }^{11}$ Pode parecer paradoxal a um compositor voltado em parte significativa de sua produção ao urbano, ou a determinadas rítmicas nativas. Contudo, saliente-se, Mignone é profundamente timbrístico e este gosto pelo som inusitado vem prioritariamente de Debussy. $\mathrm{O}$ orquestral grandiloqüente de Mignone tecladista é tantas vezes o inverso das baixas intensidades de Debussy e determinados procedimentos seletivos pensados em $\mathrm{ff}$ por Mignone, se reduzidos às baixas intensidades sonoras coloquiais, mostrariam parte do perfil do compositor francês.

Se, no código técnico-pianístico de Mignone, certos procedimentos que faziam parte do utilizado por Debussy estão presentes, como determinadas disposições de formas arpejadas comuns na obra deste, gosto pelos planos sonoros "aparentemente" independentes em abrangência tecladística, é sobremaneira na qualidade do som que se pode perceber mais nitidamente a contribuição debussysta. Após filtração no pensamento versátil de Mignone, procedimentos claramente timbrísticos se metamorfoseiam trazendo resultados inusitados. ${ }^{12}$

Entre os recursos timbrísticos, como a clara distinção dos planos sonoros em visão orquestral - na qual Mignone se mostraria um profundo conhecedor - distante da individual presença do violão em "non legato" existente nas peças de caráter urbano, um, contudo, chama particularmente a atenção pela extrema variedade que o autor sabe dele tirar proveito, na conservação de um ou mais sons de um acorde ou cluster. ${ }^{13}$

Em estado bem embrionário, tem-se um valor se prolongando e os outros executados no mesmo instante, tendo duração abreviada, como em Formiguinhas trabaIhando (v. exemplo 22).

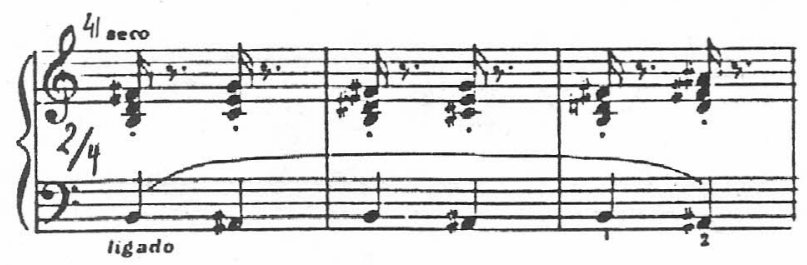


No início do IV dos $61 / 2$ Prelúdios, a configuração do legato delineia-se através de um processo de substituição dos dedos, quanto ao dedilhado, e a oitava permanecendo num expressivo canto é dimensionada pelas notas "secas" de curtíssima duração, resultando quadro timbrístico seletivo (v. exemplo 23).

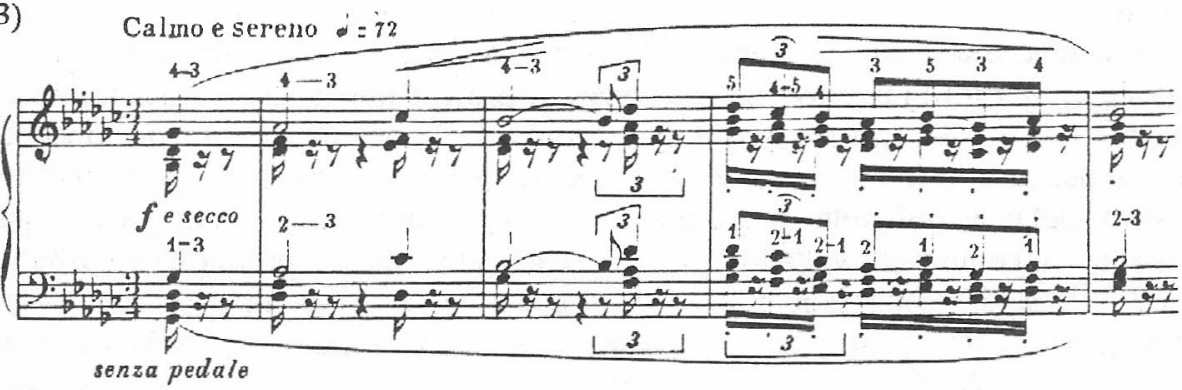

Em outra oportunidade, Mignone, após clusters em distanciamento de duas oitavas, deixa permanecer apenas uma nota de cada, num intervalo de dupla oitava, como no início do segundo movimento da 1a. Sonata (v. exemplo 24).

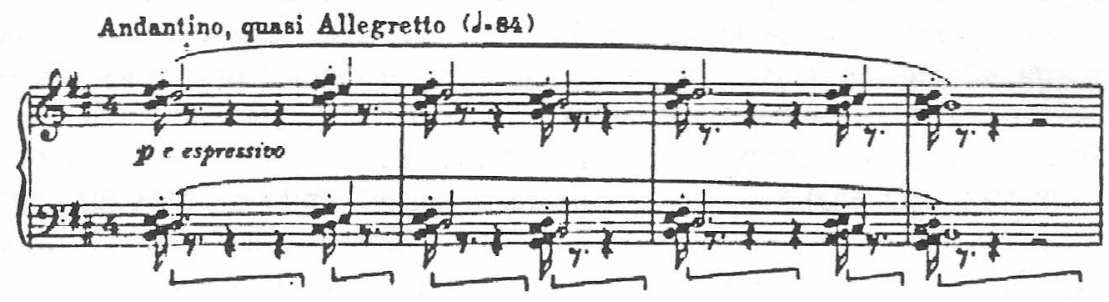

Esse processo se apresenta mais complexo quando um $s 6$ cluster enriquecido pela execução por ambas as mãos próximas deixa prosseguir sonoramente a oitava apenas. Exemplo típico é encontrado na 2a. Sonata, em seu terceiro movimento (v. exemplo 25):

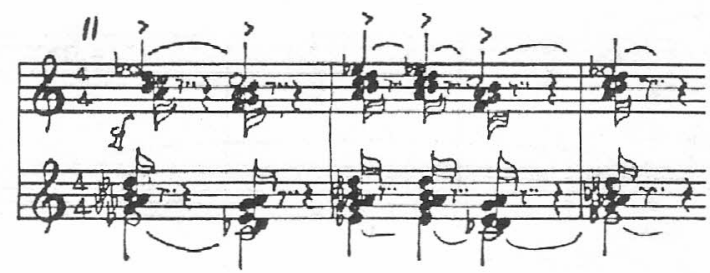


$\mathrm{Na} 4 a$. Sonata, o cluster formado por notas executadas seqüencialmente, dimensiona a continuação da linha melódica (v. exemplo 26):

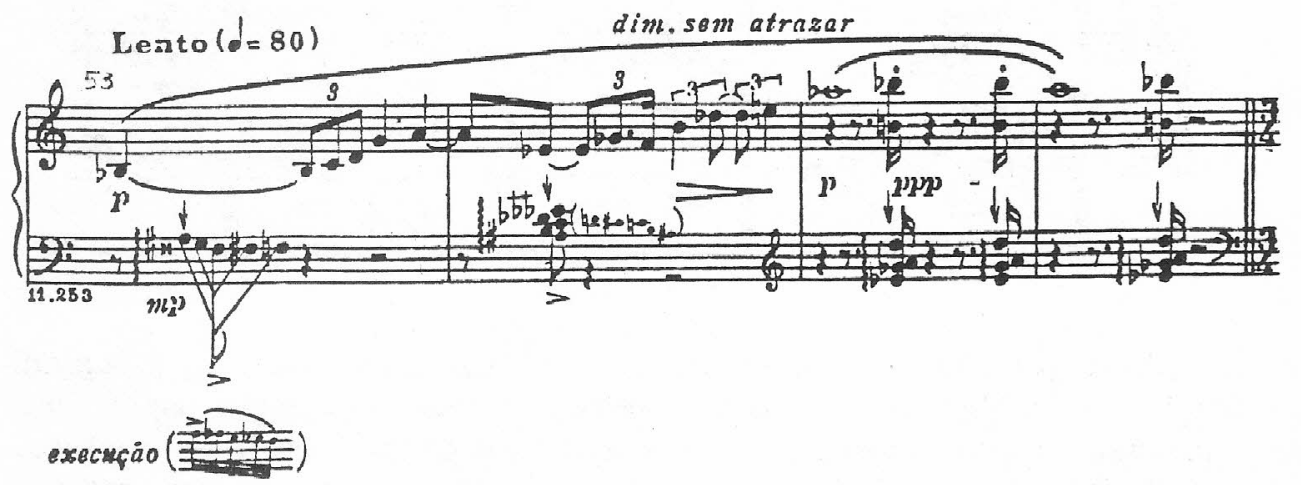

A volúpia do prolongamento de sons após outros extintos verifica-se igualmente em segmentos onde a participação do pedal torna-se imperativa. Exemplo típico encontra-se no Concerto para piano e orquestra (v. exemplo 27):

Página 37
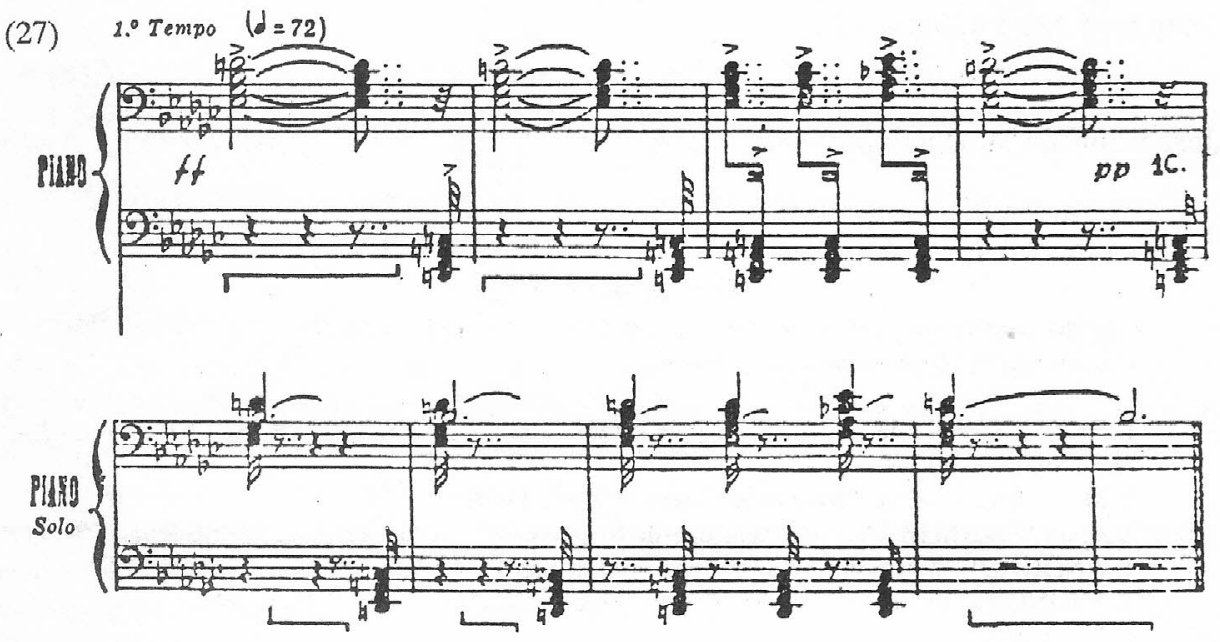

Como nâo pensar em Debussy no culto às baixas intensidades?

Decorre visão timbrística, quando em A Morte de Anhangüera, através de rápido cluster cromático, precedido de um acorde pleno em Mi menor, Mignone, abandonando este, preserva a conseqüência cromática até a extinção das sonoridades (v. exemplo 28): 
(28)

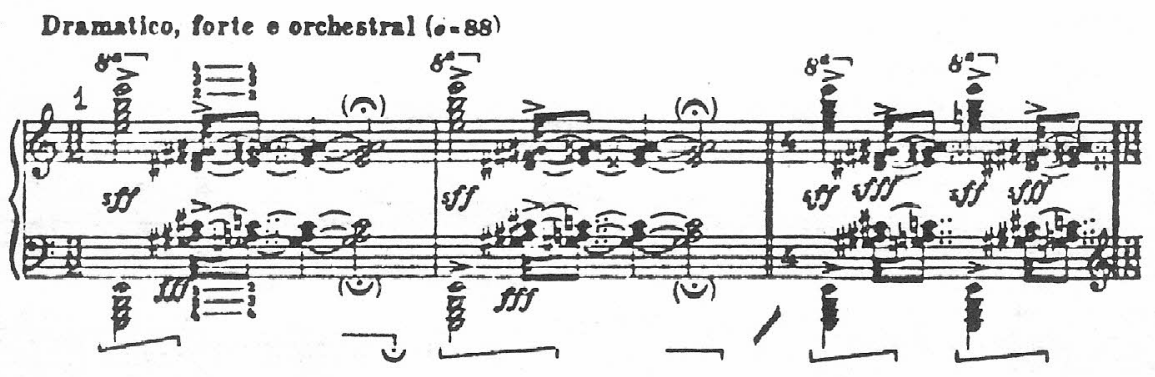

A esta panorâmica básica abordada sucintamente neste ensaio, ter-se-ia a ratificação que em Mignone caminham paralelas à intuição e elaboração, improvisação e pesquisa. $O$ autor freqüenta as várias tendências composicionais que conheceu, sem preocupação cronológica, o que o torna, paradoxalmente, um personalíssimo na música escrita no Brasil e que tão desconcertante se evidencia, compreendendose a permanência da identidade - no correr de produções antagônicas - através do emprego sistemático dos processos típicos.

Mignone representa a abrangência pianística brasileira intuitivo-cerebral através de caminho inusitado. Voltar-se ao estudo de sua obra como um todo é necessidade imperiosa. Sem este retorno, a história da música para piano, no Brasil, ficará simplesmente empobrecida.

José Eduardo Martinsé professor associado do Departamento de Música da ECA/USP.

\section{Notas e Referências}

* Artigo inédito, que deveria constar da coletânea de estudos coordenada por Vasco Mariz, sob encomenda da, hoje, extinta FUNARTE.

1. Entrevista realizada por Carlos Roque e publicada na revista Interview. São Paulo, Inter Editora, n. 49 , maio de 1982 , p. 42.

2. MANUEL, Roland, Plaisir de la musique. Paris, Du Seuil, 1947. p. 99.

3. Apud Vasco Mariz, História da música no Brasil. Rio de Janeiro, Civilização Brasileira, 1981. p. 191.

4. ANDRADE, Mário de. Música, doce música. São Paulo, L.G.Miranda, 1933. p. 317.

5. MIGNONE, Francisco. A parte do anjo. São Paulo, Mangione, 1947. p. 39.

6. Id., ibidem.

7. Seguida, dedicada a Maria Helena Coelho de Andrade, foi objeto de Dissertação de Mestrado, sob o título: Da compreensão e interpretação de uma peça inédita de Francisco Mignone através do conhecimento das características composicionais do autor. Na mesma, a autora desenvolve uma bem elaborada pesquisa comparativa da obra dedicada, com determinadas outras produçóes de Mignone para piano. Aborda processos pianísticos, rítmicos e de estruturas. Um mapeamento é feito pela autora, de alguns dos principais elementos da técnica pianística de Mignone.

8. Mignone utiliza-se de cluster "pleno" e do cluster em que as notas são tocadas seqüencialmente, à maneira de um "arpejo" que pode ter valor diminuído, o que o torna curto e até "seco". Este processo "arpejado", quando há a prolongação do valor pela duração do mesmo ou pela utiliza- 
ção do pedal, provocará um cluster que denominariamos "fluido", pois a continuaçăo sonora produz uma reintegração - pela própria continuidade - à sensação do cluster "pleno".

9. MIGNONE, Francisco, op. cit., p. 34.

10. Id., ib., p. 40.

11. Em recital comemorativo aos 60 anos da morte de Debussy, e inteiramente dedicado a suas obras, realizado na Sala Ibam do Rio de Janeiro por este intérprete, Mignone confirmava ter sido Debussy o compositor que mais o marcara quanto ao timbre e aos prolongamentos sonoros.

12. Verificar exemplo número 12

13. Na música tecladística durante o barroco, chamava-se "acciaccatura" a presença de uma nota dissonante em um acorde que, após a execução, tinha o seu valor abreviado, para que apenas o acorde consonante vibrasse. Esta prática antiga, utilizada de maneira diferenciada nos séculos posteriores, tem interesse para Mignone. 


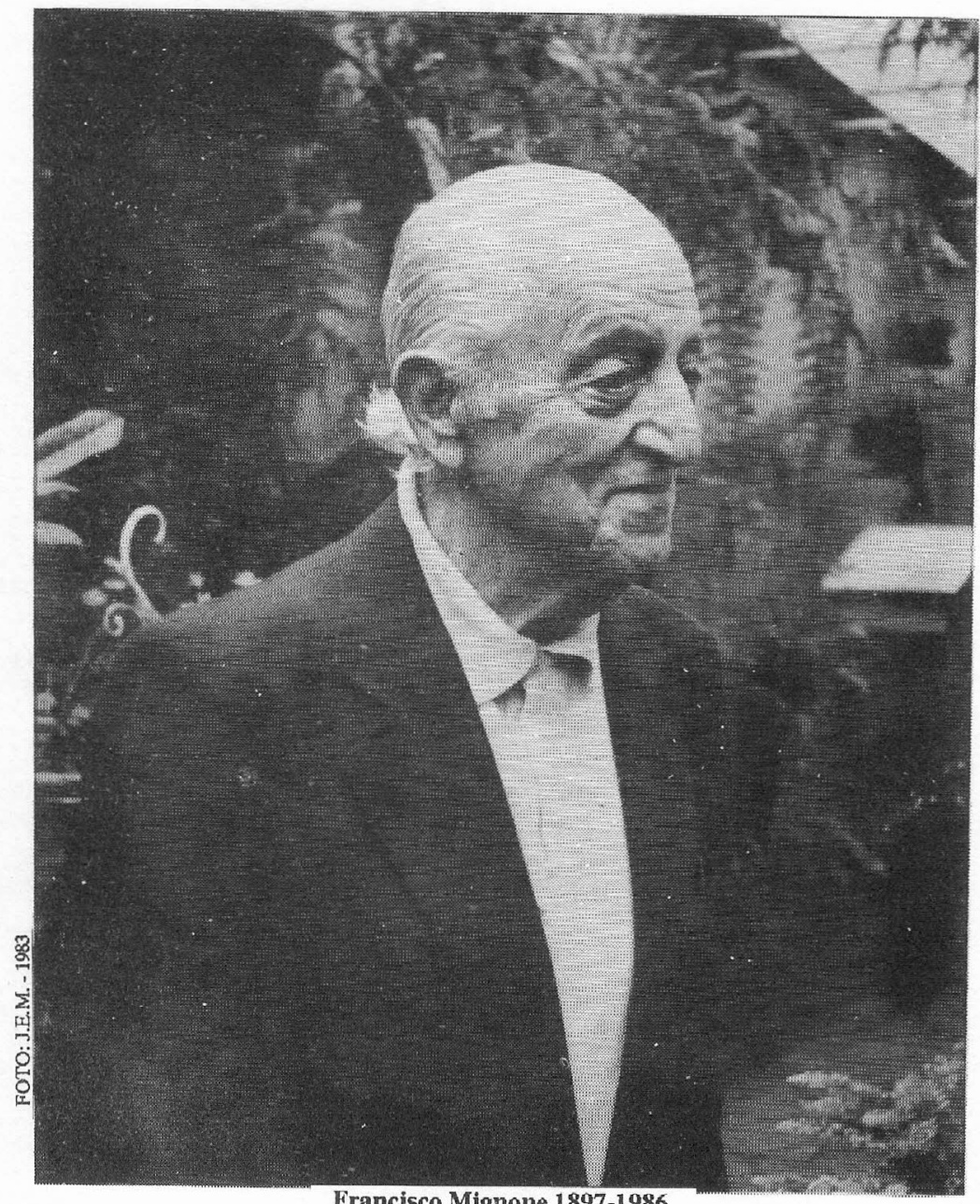

Francisco Mignone 1897-1986 